\title{
Antimicrobial and Antibiofilm Effect of Hydrogel with Origanum vulgare on Culture of Streptococcus mutans and Streptococcus sobrinus
}

\author{
Efecto Antimicrobiano y Antibiofilm de Hidrogel a Base de Origanum vulgare \\ sobre Cultivo de Streptococcus mutans y Streptococcus sobrinus
}

Vaca Chávez Maricarmen; Rodríguez Rojas Jorge Jesús²; Uziel Castillo Velázquez; Hernández Delgadillo René1; Sánchez Casas Rosa María3; Chávez Montes Abelardo4; Báez González Juan Gabriel4; Rodríguez Rodríguez José5; Martínez Delgado Ameyalli Jocelyn ${ }^{1} \&$ Rodríguez Luis Osvelia Esmeralda ${ }^{1}$

VACA C. M.; RODRÍGUEZ, R. J. J.; CASTILLO, V. U.; HERNÁNDEZ, D. R.; SÁNCHEZ, C. R. M.; CHÁVEZ, M. A.; BÁEZ, G. J. G.; RODRÍGUEZ, R. J.; MARTÍNEZ, D. A. J. \& RODRÍGUEZ, L. O. E. Antimicrobial and antibiofilm effect of hydrogel with Origanum vulgare on culture of Streptococcus mutans and Streptococcus sobrinus. Int. J. Odontostomat., 15(1):213221, 2021.

ABSTRACT: The oral cavity is an ecosystem that provides ideal conditions for the growth of bacteria, the Streptococcus genus is important for the formation of biofilms that lead to the development of dental caries, which affects the population worldwide. The world health organization encourages the use of plants thanks to its various therapeutic actions. Origanum vulgare L. (oregano), is an aromatic plant with medicinal and culinary properties. The objective of this study was to investigate the in vitro antimicrobial and antibiofilm activity of the ethanolic extract of oregano, against the growth of Streptococcus mutans and Streptococcus sobrinus ATCC. Leaves of the plant were obtained and the ethanolic extract was made by maceration. Antimicrobial activity was evaluated using the Kirby-Bauer method and compared with $2 \%$ chlorhexidine, subsequently the extract was incorporated into a hydrogel and its effect on biofilm formation was assessed by fluorescence microscopy and the main compounds were identified. present in the extratco. The study revealed that the extract presented antimicrobial effect against both strains and at $2 \%$ it showed high antimicrobial action compared to chlorhexidine at the same concentration, with average inhibition halos of $26.3 \mathrm{~mm}$ and $19 \mathrm{~mm}$ for each microorganism analyzed, ( $p<0.05$ ). Likewise, the hydrogel prepared with $2 \%$ extract significantly eliminated the preformed Streptococcus biofilm, at 24 hours of exposure, due to the presence of a variety of chemical groups, such as sterols, triterpenes, flavonoids, flavanones, flavanonols, lactones. sesquiterpenic, tannins and coumarins. The oregano extract presented high antimicrobial action for both species, with a greater effect towards Streptococcus mutans and an interesting antibiofilm action; These results show the importance of exploring treatment alternatives of plant origin, to be considered as interesting complementary aids in dental therapy. sobrinus.

KEY WORDS: biofilms, dental plaque, Origanum vulgare, phytotherapy, Streptococcus mutans, Streptococcus

\section{INTRODUCTION}

Dental plaques are microbial biofilms composed of approximately 100 different types of microorganisms, mainly bacteria, that are embedded in a matrix of extracellular polymeric substances that adhere to tooth surfaces and can cause carious lesions (Larsen \&
Fiehn, 2017; Yu et al., 2017). Streptococcus mutans and Streptococcus sobrinus are the main oral biofilmforming microorganisms responsible for the development of dental caries (Fragkou et al., 2016). Dental caries is a prevalent chronic oral disease that

\footnotetext{
${ }^{1}$ Universidad Autónoma de Nuevo León, Facultad de Odontología, 64460 Monterrey, Nuevo León, México.

2 Universidad Autónoma de Nuevo León, Centro de Investigación y Desarrollo en Ciencias de la Salud, 64460 Monterrey, Nuevo León, México

${ }^{3}$ Universidad Autónoma de Nuevo León, Facultad de Medicina Veterinaria y Zootecnia, 66050 General Escobedo, Nuevo León, México.

${ }^{4}$ Universidad Autónoma de Nuevo León, Facultad de Ciencias Biológicas, 66455 San Nicolás de los Garza, Nuevo León, México.

${ }^{5}$ Tecnológico de Monterrey, Monterrey, Nuevo León, 64849, México.
} 
VACA C. M.; RODRÍGUEZ, R. J. J.; CASTILLO, V. U.; HERNÁNDEZ, D. R.; SÁNCHEZ, C. R. M.; CHÁVEZ, M. A.; BÁEZ, G. J. G.; RODRÍGUEZ, R. J.; MARTíNEZ, D. A. J. \& RODRÍGUEZ, L. O. E. Antimicrobial and antibiofilm effect of hydrogel with Origanum vulgare on culture of Streptococcus mutans and Streptococcus sobrinus. Int. J. Odontostomat., 15(1):213-221, 2021

occurs due to the demineralization of the hard tissues of the tooth by the organic acids formed by oral bacteria present in the biofilm. Worldwide, approximately $90 \%$ of children have dental caries (Marcenes et al., 2013; Marinho et al., 2003), and in Mexico, it is estimated that $73.3 \%$ of children between 2 and 5 years have this disease (Lomelí Buyoli \& Rodríguez González, 2017).

Over the years, it has been shown that plants can produce a large number of bioactive compounds, justifying their use in traditional medicine to controlvarious pathogens (Altemimi et al., 2017). Origanum vulgare is an aromatic plant belonging to the Lamiaceae family used as a spice and in traditional medicine because of its antimicrobial, antispasmodic, anti-inflammatory, analgesic and antipyretic properties (Al-Tameme et al., 2015). Its biological activity has been attributed to compounds such as thymol, carvacrol, p-cymene, yterpinene and linalool (Sarikurkcu et al., 2015).

Among the different strategies for incorporating therapeutic agents that can be administered in a localized area are hydrogels, defined as fluid, semisolid or solid compounds formed by polymer chains with hydrophilic structures capable of retaining large amounts of water in their three-dimensional networks (Ahmed, 2015) that exhibit viscosity, that is, resistance of the gel to be deformed (Choe et al., 2018). They are used in various biomedical areas, including dentistry, because by integrating biologically active agents in their structure, they allow controlled release and provide protection (Buwalda et al., 2017), in addition to being able to eliminate pathogens from biofilms associated with major oral cavity diseases (Marsh \& Zaura, 2017). Chlorhexidine is an antimicrobial agent used in the mouth to eliminate pathogens; its adverse effects have been reported: toxicity, bacterial resistance, and discoloration of teeth, restorations and the oral mucosa (López et al., 2009; Wand et al., 2016; Cieplik et al., 2019). Therefore, the aim of the present study was to evaluate the antimicrobial and antibiotic effects using Origanum vulgare extract incorporated in a hydrogel against Streptococcus mutans and Streptococcus sobrinus ATCC, oral pathogens that form biofilms and cause dental caries.

\section{MATERIAL AND METHOD}

Obtaining the extract. Ethanolic extract was obtained by cold maceration. The dried leaves of Origanum vulgare available in a market in the city of Monterrey, N.L., Mexico, were acquired and ground, and $76.98 \mathrm{~g}$ of plant was placed into $400 \mathrm{~mL}$ of ethanol in an amber flask for 9 days at room temperature. The mixture was filtered through Whatman No. 2 paper, and the solvent was removed by evaporation under reduced pressure for 2 hours at $40^{\circ} \mathrm{C}$ using a Büchiß Rotavapor R-205. The resulting extract was. Placed in an amber vial at 4 ${ }^{\circ} \mathrm{C}$ until use (Habibi et al., 2015; Coccimiglio, et al., 2016).

Antimicrobial testing of the extract. The antimicrobial effect of the Origanum vulgare extract against Streptococcus mutans (700611) and Streptococcus sobrinus (27607) ATCC was analysed. First, the microorganisms were reactivated and reseeded in trypticasein soy broth; two to three colonies were inoculated, and the inoculum was adjusted to a 0.5 McFarland standard equivalent to $1 \times 106 \mathrm{CFU} / \mathrm{mL}$. Subsequently, antimicrobial analysis was performed by the disc diffusion method (Kirby-Bauer method) six times, and $100 \mathrm{~mL}$ of the adjusted inoculum was placed on Müller Hinton agar culture medium. Five serial concentrations of the extract were evaluated [from 2 $\%$ to $.02 \% \mathrm{w} / \mathrm{v}$ ] and incubated at $37^{\circ} \mathrm{C}$ for 24 hours. The inhibition halos were measured with a calliper, and the results were compared with a positive chlorhexidine $2 \% \mathrm{w} / \mathrm{v}$ control and negative ethanol control (Bauer et al., 1966; Roozegar et al., 2016). The percentage of the relative inhibitory effect of the extract was calculated, interpreted as high inhibitory activity $(>70$ $\%$ ), intermediate inhibitory activity (between 50 and 70 $\%$ ) and low inhibitory activity (<50\%) using the following formula (Ramírez \& Díaz, 2007; Cruz-Carrillo et al., 2010).

$\%$ inhibition $=\frac{\bar{x} \text { halo diameter of extract }}{\bar{x} \text { halo diameter of positive control }} \times 100$

Hydrogel preparation. A hydrogel with $2 \%$ Origanum vulgare extract was prepared. One hundred millilitres of sterile distilled water was placed in a beaker, and the acrylic acid polymer Carbopol $® 940 \mathrm{NF}$ at $1 \%$, w/ $\mathrm{v}$, was incorporated; subsequently, $20 \mathrm{~mL}$ of glycerine was added and then mixed with a mechanical stirrer at $200 \mathrm{rpm}$ for $20 \mathrm{~min}$ at $25^{\circ} \mathrm{C}$. The extract was incorporated until it was integrated into the gel. Lastly, triethanolamine was added, incorporating three drops, to neutralize and reach the desired viscosity and as a pH balancer (Zhang et al., 2016; Singh et al., 2016). The viscosity of the hydrogel was evaluated by emulsion flow curves using a rotational test with a Reolab QC rheometer as a function of the shear rate ( 0.02 to $100 \mathrm{~s}-1)$, using cylindrical concentric geometry CC-27 at a temperature of $27^{\circ} \mathrm{C}$ (Bociaga et al., 2019). 
VACA C. M.; RODRÍGUEZ, R. J. J.; CASTILLO, V. U.; HERNÁNDEZ, D. R.; SÁNCHEZ, C. R. M.; CHÁVEZ, M. A.; BÁEZ, G. J. G.; RODRÍGUEZ, R. J.; MARTíNEZ, D. A. J. \& RODRÍGUEZ, L. O. E. Antimicrobial and antibiofilm effect of hydrogel with Origanum vulgare on culture of Streptococcus mutans and Streptococcus sobrinus. Int. J. Odontostomat., 15(1):213-221, 2021.

Antimicrobial tests of the hydrogel extract. The antibiotic effect of the bioadhesive gel on a mixed culture of Streptococcus mutans and Streptococcus sobrinus ATCC was determined in 96-well polystyrene flat bottom plates. Bacterial inocula were cultured in trypticase soy broth in the presence of $2 \%$ extract. As a negative control, inoculum without bacteria and an ethanolic medium were used. The plates were incubated at $37^{\circ} \mathrm{C}$ for 24 hours; the supernatant was removed, and the plates were air dried for $30 \mathrm{~min}$; the wells were stained for 15 min with $0.1 \%$ aqueous crystal violet solution, and then $250 \mathrm{~mL}$ of ethanol was added to each well. After $15 \mathrm{~min}$ of incubation, the optical density was measured using a microplate reader at a wavelength of $560 \mathrm{~nm}$. The biofilm formation index (BFI) was calculated (Teh et al., 2010; Han et al., 2016) based on the optical density of the adhered crystal violet-stained microorganisms $(A B)$, the negative control culture medium (CW) and the optical density of the growth control $(G)$ using the following formula:

$$
B F I=(A B-C W) / G
$$

Additionally, all treatments were labelled with DAPI to determine their antibiotic activity, and images were taken using an inverted microscope at a wavelength of $358 \mathrm{~nm}$.

Basic phytochemical analysis. Subsequently, phytochemical screening of the extract by conventional chemical tests was performed to determine the main chemical groups present in the extract and to characterize the extract using the following tests: Liebermann Burchard (sterols and triterpenes), Shinoda (flavonoids, flavanones and flavanonols), Baljet (sesquiterpene lactones), sulfuric acid (quinones), ferric chloride (tannins), Molisch (carbohydrates), sodium hydroxide (coumarins) and Dragendorff (alkaloids) (Pérez Hernández et al., 2015; Elizondo-Luévano et al., 2018). Lastly, GC-MS chromatography $((6890 / 5973 N)$, Agilent Technologies, Santa Clara, CA, USA) was performed on a sample of the extract obtained. Gas chromatography (GC) was conducted in a HP-5 MS (30 m x $0.25 \mathrm{~mm}$ to $0.25 \mathrm{~m}$ ) capillary column. The GC conditions were as follows: injection temperature, $250{ }^{\circ} \mathrm{C}$; and oven temperature controlled at $70^{\circ} \mathrm{C}$ for 1 min with a heating rate of $10^{\circ} \mathrm{C} / \mathrm{min}$, at $200^{\circ} \mathrm{C}$ for $2 \mathrm{~min}$, with a heating rate of $10^{\circ} \mathrm{C} / \mathrm{min}$, and at $300{ }^{\circ} \mathrm{C}$ for $5 \mathrm{~min}$. The following parameters were used for the EM 5973N analysis: ion source, El; electronic energy, 70 e; quadrupole temperature, $150{ }^{\circ} \mathrm{C}$; interface temperature, $230{ }^{\circ} \mathrm{C}$; and m/z, 30-400 amu (Torres-Alvarez et al., 2017; Rostro-Alanis et al., 2019).

All experiments were performed in triplicate at least three times. Statistical analyses were performed using SPSS version 25.0 (SPSS Inc., Chicago, Illinois, USA). Normality was determined with the KolmogorovSmirnov test with a level of significance of $p<0.05$ ). Subsequently, a comparison was made between the medians of the extract concentrations and the inhibition zone with the Mann-Whitney test, with a level of significance of $p<0.05$ ).

\section{RESULTS}

The Origanum vulgare extract showed an antimicrobial effect against both strains at various concentrations. For Streptococcus mutans, the mean inhibition halo was $26.3 \mathrm{~mm}$ with $2 \%$ extract and 16 $\mathrm{mm}$ with $0.25 \%$ extract (Fig. 1). Against Streptococcus sobrinus, mean inhibition halos of 19 $\mathrm{mm}$ and $14 \mathrm{~mm}$ were obtained with $2 \%$ extract and $0.12 \%$ extract, respectively (Fig. 2 ). For both bacteria, the extract presented a high inhibition compared to that with the positive control, i.e., inhibition halos of $15 \mathrm{~mm}$. The data did not present a normal distribution based on the Kolmogorov-Smirnov normality test, either for $S$. mutans $(Z=0.288, p=$ $0.000)$ or for $S$. sobrinus $(Z=0.237, p=0.003)$, because the $p$ was less than 0.05 . With these results, a nonparametric Kruskal-Wallis analysis was performed, with a level of significance of $p \leq 0.05$ ). There was only a significant difference in extract

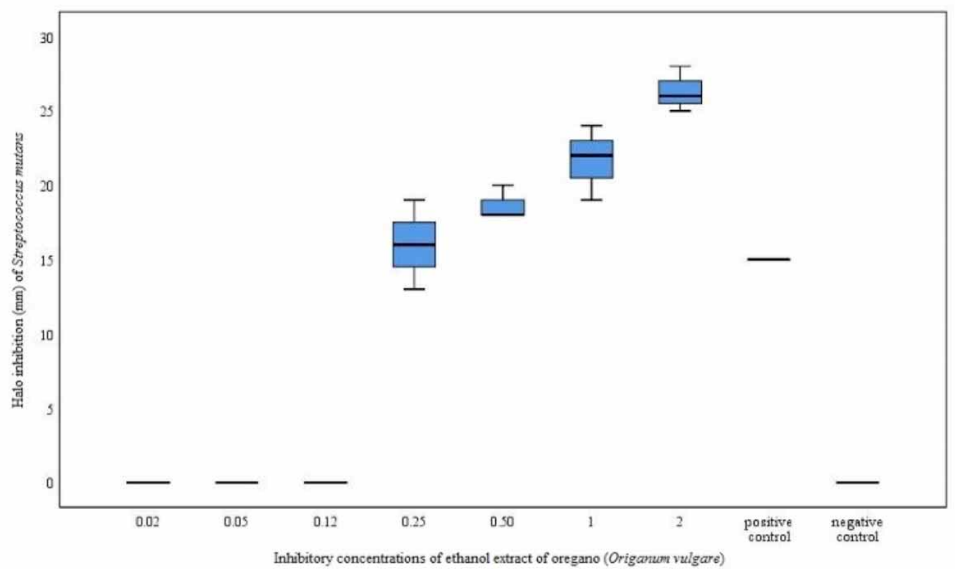

Fig. 1. Inhibition of the extract of Origanum vulgare against Streptococcus mutans. 
VACA C. M.; RODRÍGUEZ, R. J. J.; CASTILLO, V. U.; HERNÁNDEZ, D. R.; SÁNCHEZ, C. R. M.; CHÁVEZ, M. A.; BÁEZ, G. J. G.; RODRÍGUEZ, R. J.; MARTÍNEZ, D. A. J. \& RODRÍGUEZ, L. O. E. Antimicrobial and antibiofilm effect of hydrogel with Origanum vulgare on culture of Streptococcus mutans and Streptococcus sobrinus. Int. J. Odontostomat. 15(1):213-221, 2021.

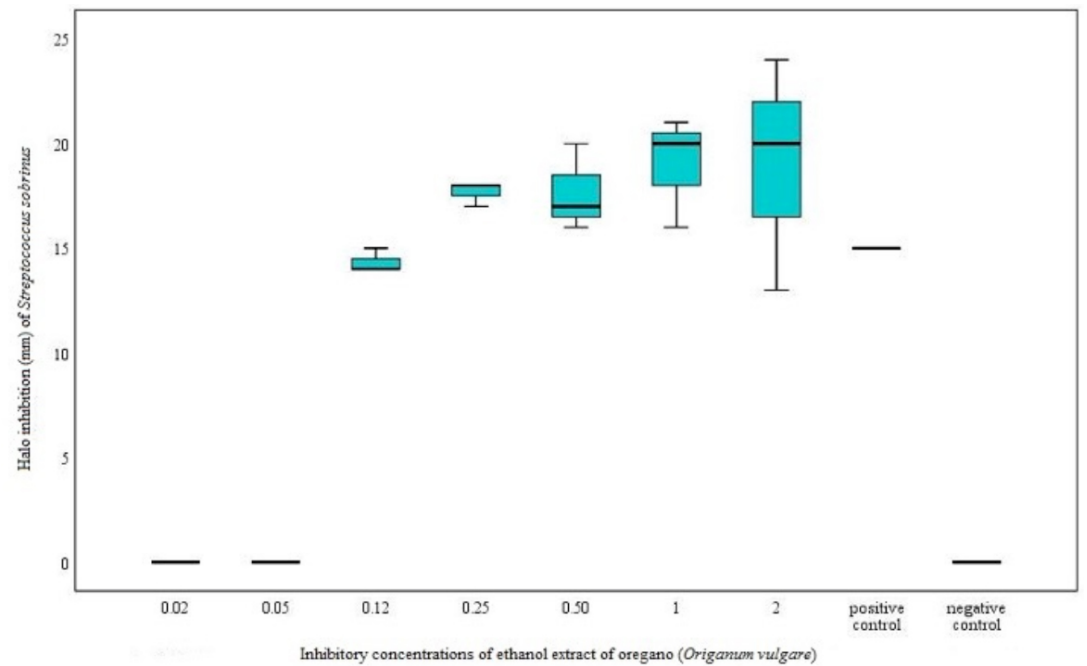

Fig. 2. Inhibition of the extract of Origanum vulgare against Streptococcus sobrinus.

inhibitory concentrations against $S$. mutans $(\mathrm{H}=$ $19.215, \mathrm{df}=6, \mathrm{p}=0.004)$, not $\mathrm{S}$. sobrinus $(\mathrm{H}=15.337$; $\mathrm{df}=6, \mathrm{p}=0.18)$. For this, a Mann-Whitney test was performed to compare the medians of the S. mutans treatments. Likewise, a comparison of the medians of the positive control and negative control was performed with the $S$. mutans and S. sobrinus treatments using the Mann-Whitney test (Table I).

Table I. Inhibitory concentrations of the extract of Origanum vulgare on Streptococcus mutans and Streptococcus sobrinus.

\begin{tabular}{|c|c|c|c|c|c|c|}
\hline \multirow[t]{2}{*}{$\begin{array}{l}\text { Extract } \\
\text { concentration ( \%) }\end{array}$} & \multicolumn{2}{|c|}{ Halo inhibition (mm) } & \multicolumn{2}{|c|}{$\%$ relative inhibition } & \multicolumn{2}{|c|}{ Significance $(P>0.05)$} \\
\hline & S. mutans & S. sobrinus & S. mutans & S. sobrinus & S. mutans & S. sobrinus \\
\hline 0.02 & 0 & 0 & 0 & 0 & a & $a^{*}$ \\
\hline 0.05 & 0 & 0 & 0 & 0 & a & $a^{*}$ \\
\hline 0.12 & 0 & 14 & 0 & 95 & $a^{*}$ & $a^{*}$ \\
\hline 0.25 & 16 & 17 & 106 & 117 & $b^{*}$ & $a^{*}$ \\
\hline 0.5 & 18 & 17 & 124 & 117 & $b^{*}$ & $a^{*}$ \\
\hline 1 & 21 & 19 & 144 & 126 & $b^{*}$ & $a^{*}$ \\
\hline 2 & 26 & 19 & 175 & 126 & $c^{*}$ & $a^{*}$ \\
\hline C- & 0 & 0 & - & - & _ & - \\
\hline $\mathrm{C}+$ & 15 & 15 & - & - & $\bar{*}$ & $\bar{*}$ \\
\hline
\end{tabular}

The data did not show normal distribution ( $\mathrm{P} \leq 0.05$, Kolmogórov-Smirnov). Negative control (C-), positive control $(\mathrm{C}+)$. a, b, c. Average range (median) with similar letters were not significantly different. Comparison between the median concentrations of the extract and the inhibition halo ( $P \leq 0.05$, Mann-Whitney test).

Comparison between the positive control group * $(P \leq 0.05$, Mann Whitney) and the treatment groups.

Comparison between the negative control group? ( $\mathrm{P} \leq 0.05$, Mann Whitney) and the treatment groups.

The hydrogel with $2 \%$ Origanum vulgare extract presented a flow curve, and when plotting the shear stress $(\mathrm{z}, \mathrm{Pa})$ vs. strain rate $\left({ }^{\circ}, \mathrm{s}-1\right)$, as the shear rates increased, the shear stress also increased (Fig. $3 a)$; with a viscosity that decreased as the rate with which the fluid in motion increased, the initial viscosity at a rate of 0.1 was $240 \mathrm{~Pa} \cdot \mathrm{s}$ and ended at $0.908 \mathrm{~Pa} \cdot \mathrm{s}$ at a strain rate of $100 \mathrm{~s}-1$. Compared to the viscosity of water, i.e., $0.001 \mathrm{~Pa} \cdot \mathrm{s}$, the hydrogel had higher viscosity (Fig. $3 \mathrm{~b}$ ); that is, a non-Newtonian pseudoplastic behaviour was obtained.

Regarding the antibiotic effect of the $2 \%$ Origanum vulgare hydrogel on a mixed culture of $S$. mutans and S. sobrinus, the biofilm was reduced by $91 \%$ at 24 hours, and for the positive control 
VACA C. M.; RODRÍGUEZ, R. J. J.; CASTILLO, V. U.; HERNÁNDEZ, D. R.; SÁNCHEZ, C. R. M.; CHÁVEZ, M. A.; BÁEZ, G. J. G.; RODRÍGUEZ, R. J.; MARTÍNEZ, D. A. J. \& RODRÍGUEZ, L. O. E. Antimicrobial and antibiofilm effect of hydrogel with Origanum vulgare on culture of Streptococcus mutans and Streptococcus sobrinus. Int. J. Odontostomat., 15(1):213-221, 2021.
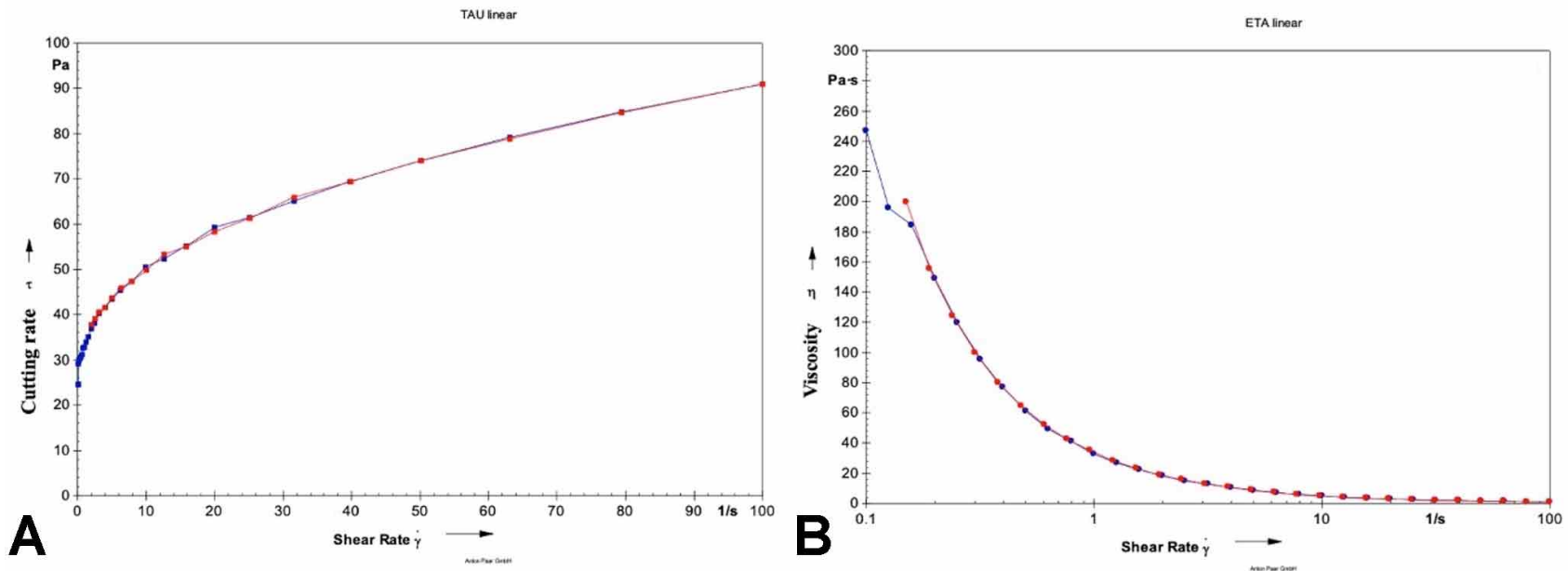

Fig. 3. Hydrogel characteristics. a) Hydrogel flow curve, b) Hydrogel viscosity curve.

(chlorhexidine $2 \%$ ), the biofilm was reduced by $56 \%$, results that were corroborated with fluorescence images (Fig. 4). Therefore, the Wilcoxon signed-ranks test was performed for the subsequent treatment comparisons; the differences were all significant $(\mathrm{P} \leq$ 0.05) (Tables II and III).

Table II. Descriptive statistics of antibiofilm activity.

\begin{tabular}{|c|c|c|c|c|c|}
\hline & $\begin{array}{l}\text { Gel.chx.2 } \\
\text { Gel.tx.25 }\end{array}$ & $\begin{array}{ll}\text { - } & \text { Gel.tx.25 } \\
\text { C. growth }\end{array}$ & $\begin{array}{ll}\text { - } & \text { Gel.chx.2 } \\
& \text { C.growth }\end{array}$ & $\begin{array}{ll}- & \text { Gel.tx.25 } \\
& \text { Gelc.negative }\end{array}$ & $\begin{array}{ll}\text { - } & \text { Gel.chx.2 } \\
\text { e } & \text { Gelc.negative }\end{array}$ \\
\hline Z & -3.059 & -2.803 & -2.191 & -3.059 & -2.903 \\
\hline$P$ & 0.002 & 0.005 & 0.028 & 0.002 & 0.004 \\
\hline
\end{tabular}

Table III. Partial phytochemical characterization of Origanum vulgare.

\begin{tabular}{llc}
\hline Chemical test & Compound to identify & Result \\
\hline Liebermann Burchard & Sterols & + \\
& Triterpenes & \\
Shinoda & Flavonoids & + \\
& Flavanones & \\
& Flavanonols & + \\
Baljet & Sesquiterpenlactones & - \\
Sulfuric acid & Quinones & + \\
Ferric chloride & Tannins & - \\
Molisch & Carbohydrates & + \\
Sodium hydroxide $10 \%$ & Coumarins & - \\
Dragendorff & Alkaloids &
\end{tabular}

The Origanum vulgare extract was positive for sterols, triterpenes, flavonoids, flavanones, flavanonols, sesquiterpene lactones, tannins and coumarins (Table IV). The principally identified components were carvacrol, phenol, p-cymene, thymol, 2-methyl-5-isopropylphenol (RT 10.89 - $31.39 \%$ a), 3benzenetriol, 3-trihydroxybenzene, 3-dihydroxyphenol
(RT 11.93 - $28.28 \%$ a), n-hexadecanoic acid (RT 19.31 - $8.63 \% \mathrm{a}$ ), 2-furaldehyde, 2-furancarboxaldehyde (RT $9.82-6.23 \% a$ ), linoleic acid, methyl linolenate (RT 21.59 - $6 \% a$ ), and D-glucopyranose, levoglucosan (RT $13.63-5.84 \% \mathrm{a}$ ), to which the antimicrobial and antibiotic activities of the Origanum vulgare extract were attributed (Fig. 5). 
VACA C. M.; RODRÍGUEZ, R. J. J.; CASTILLO, V. U.; HERNÁNDEZ, D. R.; SÁNCHEZ, C. R. M.; CHÁVEZ, M. A.; BÁEZ, G. J. G.; RODRÍGUEZ, R. J.; MARTÍNEZ, D. A. J. \& RODRÍGUEZ, L. O. E. Antimicrobial and antibiofilm effect of hydrogel with Origanum vulgare on culture of Streptococcus mutans and Streptococcus sobrinus. Int. J. Odontostomat. 15(1):213-221, 2021.

Biofilm mixed culture

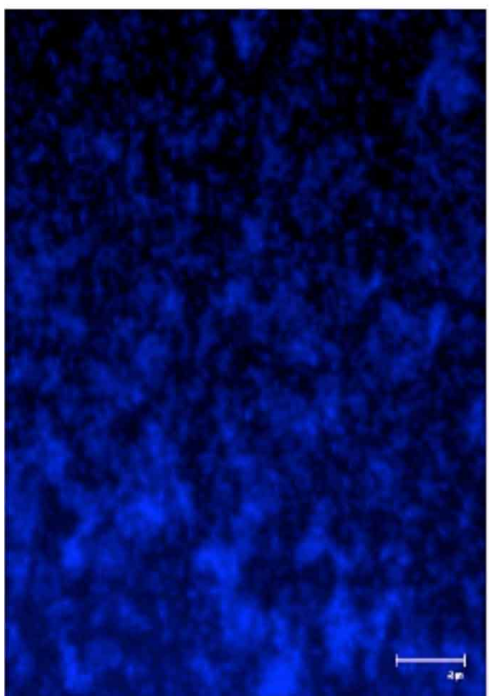

Origanum vulgare $2 \%$

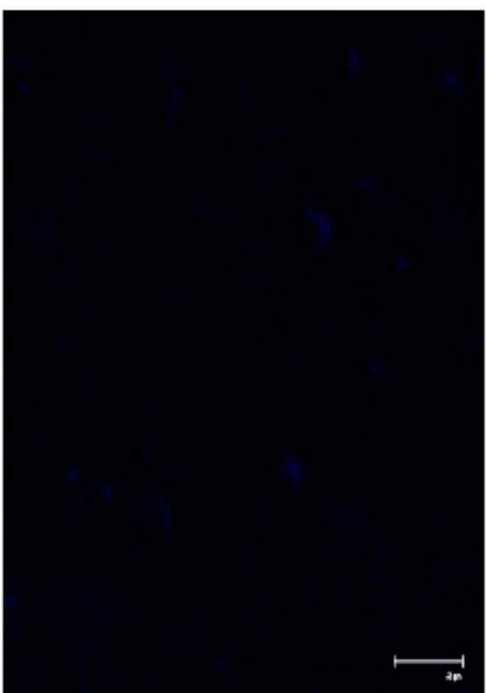

Chlorhexidine $2 \%(\mathrm{C}+)$

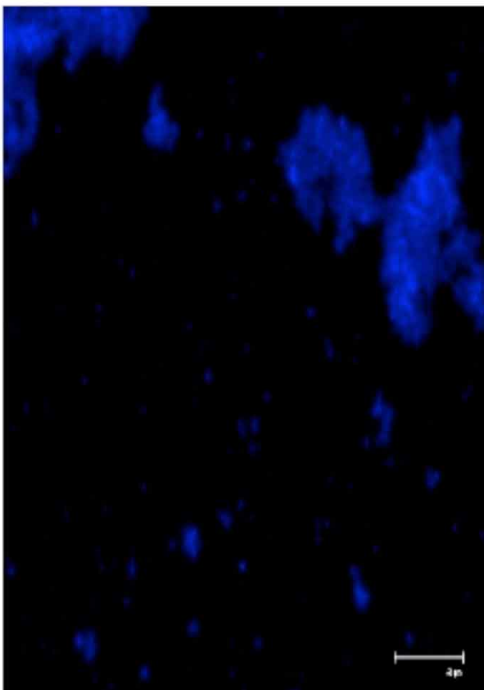

Fig. 4. Images of mixed culture plates of S. mutans and S. sobrinus stained under fluorescence microscopy. Positive control $(\mathrm{C}+)$.

Table IV. Compounds obtained in the chromatogram obtained from the GC / MS analysis of the Origanum vulgare extract.

\begin{tabular}{lll}
\hline Compounds & $\mathrm{RT}$ & $\%^{\mathrm{a}}$ \\
\hline Carvacrol, phenol, p-cymene, thymol, 2-methyl-5-isopropylphenol & 10.89 & 31.39 \\
3-benzenetriol, 3-trihydroxybenzene, 3-dihydroxyphenol & 11.93 & 28.28 \\
n-Hexadecanoic acid & 19.31 & 8.63 \\
2-furaldehyde, 2-furancarboxaldehyde & 9.82 & 6.23 \\
linoleinic acid, methyl linolenate & 21.59 & 6 \\
D-glucopyranose, levoglucosan & 13.63 & 5.84 \\
\hline
\end{tabular}

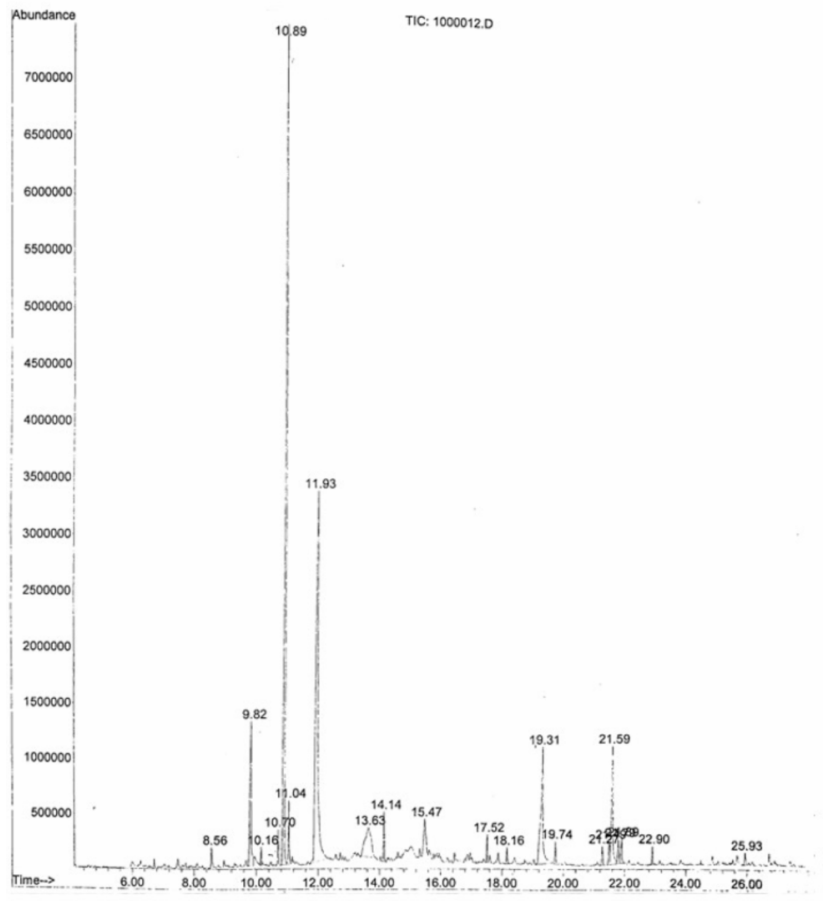

Fig. 5. Chromatogram obtained from the GC / MS analysis of the Origanum vulgare extract.

\section{DISCUSSION}

The present work highlights Origanum vulgare ethanolic extract as a good antibacterial agent. The reported results show good growth inhibition against Streptococcus sobrinus, presenting an even greater effect against Streptococcus mutans, important pathogens in the formation of oral biofilms and dental caries. These results are consistent with various studies that support its antibacterial activity. Its activity has been reported against Gram+ bacteria, such as Staphylococcus aureus, Bacillus subtilis, Enterococcus faecalis, and Streptococcus mutans, and Gram- bacteria, such as Escherichia coli, and Pseudomonas aeruginosa. The concentrations at which the extract has been shown to be active range from $2.36 \mathrm{mg} / \mathrm{mL}$ for $S$. aureus and $B$. subtilis, to $9.44 \mathrm{mg} / \mathrm{mL}$ for $E$. faecalis, $200 \mathrm{mg} / \mathrm{mL}$ for S. mutans, $4.72 \mathrm{mg} / \mathrm{mL}$ for $E$. coli. and $9.44 \mathrm{mg} / \mathrm{mL}$ for $P$. aeruginosa, showing inhibition of 20.5 , 26.9, 13.6, 9, 12.9 and $9.3 \mathrm{~mm}$, respectively (Fikry et al., 2019). In this study, inhibitory action was observed 
VACA C. M.; RODRÍGUEZ, R. J. J.; CASTILLO, V. U.; HERNÁNDEZ, D. R.; SÁNCHEZ, C. R. M.; CHÁVEZ, M. A.; BÁEZ, G. J. G.; RODRÍGUEZ, R. J.; MARTÍNEZ, D. A. J. \& RODRÍGUEZ, L. O. E. Antimicrobial and antibiofilm effect of hydrogel with Origanum vulgare on culture of Streptococcus mutans and Streptococcus sobrinus. Int. J. Odontostomat., 15(1):213-221, 2021.

at $1.2 \mathrm{mg} / \mathrm{mL}$ for $\mathrm{S}$. sobrinus and $2.5 \mathrm{mg} / \mathrm{mL}$ for $S$. mutans, concentrations similar to those reported.

The effectiveness of chlorhexidine present in mouthwash or $2 \% \mathrm{w} / \mathrm{v}$ bioadhesive gel as the main antiseptic agent used to eliminate oral bacteria (de Queiroz et al., 2016; Brambilla et al., 2017) has been described. Likewise, its adverse effects, toxicity and the emergence of antimicrobial resistance have been reported (Karpin'ski \& Szkaradkiewicz, 2015; Saleem et al., 2016; Cieplik et al.); therefore, it is important to search for alternatives based on herbal products that control oral biofilms. In this study, Origanum vulgare extract showed inhibitory activity superior to that of chlorhexidine at the same concentration. This is relevant because it is a crude extract that has been studied due to the presence of a significant variety of compounds present. Khan et al. (2017), evaluated the inhibition of S. mutans biofilm formation by thymol and carvacrol and by chlorhexidine and reported that the biofilm was significantly reduced in the presence of both thymol and carvacrol, with inhibition similar to that of chlorhexidine.

The phytochemical analysis performed on the extract revealed the presence of major compounds such as thymol and carvacrol. When the extract was incorporated at $2 \% \mathrm{w} / \mathrm{v}$ in hydrogel, the formation of biofilm after 24 hours of exposure was considerably reduced, presenting a greater inhibitory effect with better performance than the free extract at the same concentration, i.e., extract that had not been incorporated into hydrogel. An advantage of hydrogels is the slow release of the products incorporated in their structure, in addition to protecting active agents, biocompatibility with tissues and controllable degradability (Li \& Mooney, 2016). The hydrogel formulation tested in this study had a higher inhibitory effect than did the free extract at the same concentration evaluated. There have been several recent studies in which an active agent has been incorporated due to the advantages of this system; for example, Agarwal et al. (2019) developed a hydrogel formulation loaded with Theobroma cacao extract to increase the antioxidant and antimicrobial effects against different bacteria and found that the extract incorporated in hydrogel increased its bioavailability, maintaining an effective prolonged release up to 12 hours. These results agree with what was found in this study because when the Origanum vulgare extract was incorporated at $2 \% \mathrm{w} / \mathrm{v}$ in hydrogel, biofilm formation after 24 hours of exposure was considerably reduced. Raei et al. (2017), and Jafri et al. (2019), also demonstrated that thymol and carvacrol inhibit the formation of biofilm of Gram-negative bacilli, which produce carbapenemase enzymes that are important in bacterial resistance.

It has been reported that in the ethanolic extract of oregano leaf, the main compounds identified were ferulic acid, rosmarinic acid, quercetin, luteolin, apigenin, carvacrol and thymol (Chuang et al., 2018; Moghrovyan et al., 2019). In the analysis of the essential oil of oregano, a-pinene, b-myrcene, aterpinene, limonene, g-terpinene, thymol and carvacrol were present (Rostro-Alanis et al.). In this study, the presence of previously reported compounds was also identified in the ethanolic extract of Origanum vulgare by GC/MS, highlighting phenols such as thymol and carvacrol; therefore, it could be suggested that these agents are responsible for its biological activity and that their application through a polymeric formulation in hydrogel facilitates the control of dental caries.

\section{CONCLUSION}

Hydrogels improve the safety and topical application of active ingredients, providing greater action in the therapeutic area, and according to the study performed, the ethanolic extract of Origanum vulgare incorporated in hydrogel at a concentration of $2 \%$ showed important antimicrobial effects against Streptococcus mutans and Streptococcus sobrinus and showed that, at a concentration of $2 \%$, it reduced the biofilm of these microorganisms by $91 \%$, obtaining a better result than the positive control gel $(2 \%$ chlorhexidine), which reduced the same biofilm by 56 $\%$. This result is associated with the presence of a wide range of active substances in the plant material; therefore, studies with natural products are of interest because they contain compounds capable of providing favourable properties for the medical and odontological fields, reducing the risk of producing adverse effects and being a complementary alternative in oral therapy.

\section{ACKNOWLEDGMENTS}

To Universidad Autónoma de Nuevo León, for the support through the Programa de Apoyo a la Investigación Científica y Tecnológica (Paycit 2020), CN1491-20.

To Programa para el Desarrollo Profesional Docente tipo Superior (PRODEP, 2020), and to Consejo nacional de Ciencia y Tecnología for the support provided. 
VACA C. M.; RODRÍGUEZ, R. J. J.; CASTILLO, V. U.; HERNÁNDEZ, D. R.; SÁNCHEZ, C. R. M.; CHÁVEZ, M. A.; BÁEZ, G. J. G.; RODRÍGUEZ, R. J.; MARTíNEZ, D. A. J. \& RODRÍGUEZ, L. O. E. Antimicrobial and antibiofilm effect of hydrogel with Origanum vulgare on culture of Streptococcus mutans and Streptococcus sobrinus. Int. J. Odontostomat., 15(1):213-221, 2021

VACA C. M.; RODRÍGUEZ, R. J. J.; CASTILLO, V. U.; HERNÁNDEZ, D. R.; SÁNCHEZ, C. R. M.; CHÁVEZ, M. A.; BÁEZ, G. J. G.; RODRÍGUEZ, R. J.; MARTÍNEZ, D. A. J. \& RODRÍGUEZ, L. O. E. Efecto antimicrobiano y antibiofilm de hidrogel a base de Origanum vulgare sobre cultivo de Streptococcus mutans y Streptococcus sobrinus. Int. J. Odontostomat., 15(1):213-221, 2021.

RESUMEN: La cavidad oral es un ecosistema que proporciona condiciones ideales para el crecimiento de bacterias, el género Streptococcus es importante para la formación de biopelículas que conducen al desarrollo de caries dental, que afecta a la población a nivel mundial. La organización mundial de la salud, fomenta el uso de plantas gracias a sus diversas acciones terapéuticas. Origanum vulgare L. (orégano), es una planta aromática con propiedades medicinales y culinarias. El objetivo de este estudio fue investigar la actividad antimicrobiana y antibiofilm in vitro del extracto etanólico de oregano, contra el crecimiento de Streptococcus mutans y Streptococcus sobrinus ATCC. Se obtuvierón hojas de la planta y se realizó el extracto etanólico mediante maceración. La actividad antimicrobiana se evaluó mediante el método de Kirby-Bauer y se comparó con la clorhexidina al $2 \%$, posteriormente se incorporó el extracto en un hydrogel y se valoró su efecto sobre la formación del biofilm mediante microscopía de fluorescencia y se identificó los principales compuestos presentes en el extratco. El estudio reveló que el extracto presentó efecto antimicrobiano contra ambas cepas y al $2 \%$ mostró alta acción antimicrobiana en comparación con la clorhexidina a la misma concentración, con halos de inhibición promedio de 26.3 $\mathrm{mm}$ y de $19 \mathrm{~mm}$ para cada microorganismo analizado, $(\mathrm{p}<$ $0.05)$. Así mismo, el hidrogel preparado con extracto al $2 \%$, eliminó significativamente la biopelícula preformada de Streptococcus, a las 24 horas de exposición, debido a la presencia de una variedad de grupos químicos, como esteroles, triterpenos, flavonoides, flavanonas, flavanonoles, lactonas sesquiterpénicas, taninos y cumarinas. El extracto de orégano presentó alta acción antimicrobiana para ambas especies, con mayor efecto hacia el Streptococcus mutans y una acción antibiofilm interesante; estos resultados muestran la importancia de explorar en alternativas de tratamiento de origen vegetal, para considerarse como auxiliares complementarios interesantes en la terapia dental.

PALABRAS CLAVE: biofilms, placa dental, origanum, fitoterapia, Streptococcus mutans, Streptococcus sobrinus.

\section{REFERENCES}

Agarwal, S.; Tyagi, V.; Agarwal, M.; Pant, A.; Kaur, H.; Rachana \& Singh, M. Controllable transdermal drug delivery of Theobroma cacao extract based polymeric hydrogel against dermal microbial and oxidative damage. Food Nutr. Sci., 10(10):1212-35, 2019.

Ahmed, E. M. Hydrogel: Preparation, characterization, and applications: A review. J. Adv. Res., 6(2):105-21, 2015.
Al-Tameme, H. J.; Hameed, I. H.; Idan, S. A. \& Al-Masudi, H. Biochemical analysis of Origanum vulgare seeds by fouriertransform infrared (FT-IR) spectroscopy and gas chromatographymass spectrometry (GC-MS). J. Pharmacogn. Phytother., 7(9):22137,2015

Altemimi, A.; Lakhssassi, N.; Baharlouei, A.; Watson, D. G. \& Lightfoot, D. A. Phytochemicals: extraction, isolation, and identification of bioactive compounds from plant extracts. Plants (Basel), 6(4):42, 2017.

Bauer, A. W.; Kirby, W. M.; Sherris, J. C. \& Turck, M. Antibiotic susceptibility testing by a standardized single disk method. Am. J. Clin. Pathol., 45(4):493-6, 1966.

Bociaga, D.; Bartniak, M.; Grabarczyk, J. \& Przybyszewska, K. Sodium alginate/gelatine hydrogels for direct bioprinting-The effect of composition selection and applied solvents on the bioink properties. Materials, 12(17):2669, 2019.

Brambilla, E.; Lonescu, A. C.; Cazzaniga, G.; Ottobelli, M.; Mazzoni, A.; Cadenaro, M.; Gagliani, M.; Tay, F. R.; Pashley, D. H. \& Breschi, L. In vitro Streptococcus mutans biofilm formation on surfaces of chlorhexidine-containing dentin bonding systems. Int. J. Adhes. Adhes., 75:23-30, 2017.

Buwalda, S. J.; Vermonden, T. \& Hennink, W. E. Hydrogels for therapeutic delivery: current developments and future directions. Biomacromolecules, 18(2):316-s30, 2017.

Choe, D.; Kim, Y. M.; Nam, J. E.; Nam, K.; Shin, C. S. \& Roh, Y. H. Synthesis of high-strength microcrystalline cellulose hydrogel by viscosity adjustment. Carbohydr. Polym., 180:231-7, 2018.

Chuang, L. T.; Tsai, T. H.; Lien, T. J.; Huang, W. C.; Liu, J. J.; Chang, H.; Chang, M. L. \& Tsai, P. J. Ethanolic extract of Origanum vulgare suppresses Propionibacterium acnes-induced inflammatory responses in human monocyte and mouse ear edema models. Molecules, 23(8):1987, 2018.

Cieplik, F.; Jakubovics, N. S.; Buchalla, W.; Maisch, T.; Hellwig, E. \& Al-Ahmad, A. Resistance toward chlorhexidine in oral bacteria - Is there cause for concern? Front. Microbiol., 10:587, 2019.

Coccimiglio, J.; Alipour, M.; Jiang, Z. H.; Gottardo, C. \& Suntres, Z. Antioxidant, antibacterial, and cytotoxic activities of the ethanolic Origanum vulgare extract and its major constituents. Oxid. Med. Cell. Longev., 2016:1404505, 2016.

Cruz-Carrillo, A.; Rodríguez, N. N. \& Rodríguez, C. E. Evaluación in vitro del efecto antibacteriano de los extractos de Bidens pilosa, Lantana camara, Schinus molle y Silybum marianum. Rev. U.D.C.A Actual. Divulg. Cient., 13(2):117-24, 2010.

de Queiroz, V. S.; Ccahuana-Vásquez, R. A.; Tedesco, A. F.; Lyra, L.; Cury, J. A. \& Schreiber, A. Z. Streptococcus mutans biofilms. Scientifica, 2016:2816812, 2016.

Elizondo-Luévano, J. H.; Castro-Ríos, R.; Sánchez-García, E.; Hernández-García, M. E.; Vargas-Villarreal, J.; Rodríguez-Luis, O. E. \& Chávez-Montes, A. In vitro study of antiamoebic activity of methanol extracts of Argemone mexicana on trophozoites of Entamoeba histolytica HM1-IMSS. Can. J. Infect. Dis. Med. Microbiol., 2018:7453787, 2018.

Fikry, S.; Khalil, N. \& Salama, O. Chemical profiling, biostatic and biocidal dynamics of Origanum vulgare L. essential oil. AMB Express, 9:41, 2019

Fragkou, S.; Balasouli, C.; Tsuzukibashi, O.; Argyropoulou, A.; Menexes, G.; Kotsanos, N. \& Kalfas, S. Streptococcus mutans, Streptococcus sobrinus and Candida albicans in oral samples from caries-free and caries-active children. Eur. Arch. Paediatr. Dent., 17(5):367-75, 2016.

Habibi, E.; Shokrzadeh, M.; Chabra, A.; Naghshvar, F.; KeshavarzMaleki, R. \& Ahmadi, A. Protective effects of Origanum vulgare ethanol extract against cyclophosphamide-induced liver toxicity in mice. Pharm. Biol., 53(1):10-5, 2015

Han, N.; Mizan, F. R.; Jahid, I. K. \& Ha, S. D. Biofilm formation by Vibrio parahaemolyticus on food and food contact surfaces increases with rise in temperature. Food Control, 70:161-6, 2016. 
VACA C. M.; RODRÍGUEZ, R. J. J.; CASTILLO, V. U.; HERNÁNDEZ, D. R.; SÁNCHEZ, C. R. M.; CHÁVEZ, M. A.; BÁEZ, G. J. G.; RODRÍGUEZ, R. J.; MARTíNEZ, D. A. J. \& RODRÍGUEZ, L. O. E. Antimicrobial and antibiofilm effect of hydrogel with Origanum vulgare on culture of Streptococcus mutans and Streptococcus sobrinus. Int. J. Odontostomat., 15(1):213-221, 2021.

Jafri, H.; Ansari, F. A. \& Ahmad, I. Prospects of Essential Oils in Controlling Pathogenic Biofilm. In: Khan, M. S. A.; Ahmad, I. \& Chattopadhyay, D. New Look to Phytomedicine. Advancements in Herbal Products as Novel Drug Leads. New York, Elsevier, 2019. pp.203-36.

Karpinski, T. M. \& Szkaradkiewicz, A. K. Chlorhexidine--pharmacobiological activity and application. Eur. Rev. Med. Pharmacol. Sci., 19(7):1321-6, 2015

Khan, S. T.; Khan, M.; Ahmad, J.; Wahab, R.; Abd-Elkader, O. H.; Musarrat, J.; Alkhathlan, H. Z. \& Al-Kedhairy, A. A. Thymol and carvacrol induce autolysis, stress, growth inhibition and reduce the biofilm formation by Streptococcus mutans. AMB Express, 7(1):49, 2017

Larsen, T. \& Fiehn, N. E. Dental biofilm infections - an update. APMIS, 125(4):376-84, 2017.

Li, J. \& Mooney, D. J. Designing hydrogels for controlled drug delivery. Nat. Rev. Mater., 1(12):16071, 2016

Lomelí Buyoli, G. \& Rodríguez González, K. G. Resultados del Sistema de Vigilancia Epidemiológica de Patologías Bucales SIVEPAB 2017. Ciudad de México, Secretaría de Salud, Subsecretaría de Prevención y Promoción de la Salud, Dirección General de Epidemiología, Centro Nacional de Programas Preventivos y Control de Enfermedades, 2017. Disponible en: https://www.gob.mx/ cms/uploads/attachment/file/459279/SIVEPAB_2017.pdf

López, M. C. T.; Álvarez, M. D. \& Morales, A. A. La clorhexidina, bases estructurales y aplicaciones en la estomatología. Gac. Med. Espirituana, 11(1):8, 2009.

Marcenes, W.; Kassebaum, N. J.; Bernabé, E.; Flaxman, A.; Naghavi, M.; Lopez, A. \& Murray, C. J. Global burden of oral conditions in 1990-2010: a systematic analysis. J. Dent. Res., 92(7):592-7, 2013.

Marinho, V. C. C.; Higgins, J. P. T.; Logan, S. \& Sheiham, A. Fluoride mouthrinses for preventing dental caries in children and adolescents. Cochrane Database Syst. Rev., (3):CD002284, 2003.

Marsh, P. D. \& Zaura, E. Dental biofilm: ecological interactions in health and disease. J. Clin. Periodontol., 44 Suppl. 18:S12-22, 2017.

Moghrovyan, A.; Sahakyan, N.; Babayan, A.; Chichoyan, N.; Petrosyan, M. \& Trchounian, A. essential oil and ethanol extract of oregano (Origanum vulgare I.) from Armenian flora as a natural source of terpenes, flavonoids and other phytochemicals with antiradical, antioxidant, metal chelating, tyrosinase inhibitory and antibacterial activity. Curr. Pharm. Des., 25(16):1809-16, 2019.

Pérez Hernández, R. A.; Rivas, C. L.; Oranday Cárdenas, A.; Hernández Luna, C. E.; Sánchez García, E. \& Rivas Morales, C. Efecto in vitro en la inhibición del proceso de nucleación en litiasis renal, capacidad de captura de radicales libres, actividad antimicrobiana y tóxica del extracto metanólico de Berberis trifoliata. Rev. Mex. Cienc. Farm., 46(1):70-6, 2015.

Raei, P.; Pourlak, T.; Memar, M. Y.; Alizadeh, N.; Aghamali, M.; Zeinalzadeh, E.; Asgharzadeh, M. \& Kafil, H. S. Thymol and carvacrol strongly inhibit biofilm formation and growth of carbapenemase-producing Gram negative bacilli. Cell. Mol. Biol. (Noisy-le-grand), 63(5):108-12, 2017.

Ramírez, A. L. S. \& Diaz, B. H. E. Actividad antibacteriana de extractos y fracciones del ruibarbo (Rumex conglomeratus). Sci. Tech., 1(33):397-400, 2007.

Roozegar, M. A.; Jalilian, F. A.; Havasian, M. R.; Panahi, J. \& Pakzad, I. Antimicrobial effect of Pistacia atlantica leaf extract. Bioinformation, 12(1):19-21, 2016.

Rostro-Alanis, M. J.; Báez-González, J.; Torres-Alvarez, C.; ParraSaldívar, R.; Rodriguez-Rodriguez, J. \& Castillo, S. Chemical composition and biological activities of Oregano essential oil and its fractions obtained by vacuum distillation. Molecules, 24(10):1904; 2019.

Saleem, H. G. M.; Seers, C. A.; Sabri, A. N. \& Reynolds, E. C. Dental plaque bacteria with reduced susceptibility to chlorhexidine are multidrug resistant. BMC Microbiol., 16:214, 2016.
Sarikurkcu, C.; Zengin, G.; Oskay, M.; Uysal, S.; Ceylan, R. \& Aktumsek, A. Composition, antioxidant, antimicrobial and enzyme inhibition activities of two Origanum vulgare subspecies (subsp. vulgare and subsp. hirtum) essential oils. Ind. Crops Prod., 70:178-84, 2015.

Singh, M.; Kanoujia, J.; Singh, P.; Parashar, P.; Arya, M.; Tripathi, C. B.; Sinha, V. R. \& Saraf, S. A. Development of an a-linolenic acid containing a soft nanocarrier for oral delivery-part II: buccoadhesive gel. RSC Adv., 6(103):101602, 2016.

Teh, K. H.; Flint, S. \& French, N. Biofilm formation by Campylobacter jejuni in controlled mixed-microbial populations. Int. J. Food Microbiol., 143(3):118-24, 2010.

Torres-Alvarez, C.; Núñez González, A.; Rodríguez, J.; Castillo, S. Leos-Rivas, C. \& Báez-González, J. G. Chemical composition, antimicrobial, and antioxidant activities of orange essential oil and its concentrated oils. CyTA J. Food, 15(1):129-35, 2017.

Wand, M. E.; Bock, L. J.; Bonney, L. C. \& Sutton, J. M. Mechanisms of increased resistance to chlorhexidine and cross-resistance to colistin following exposure of Klebsiella pneumoniae clinical isolates to chlorhexidine. Antimicrob. Agents Chemother., 61(1):e01162-16, 2016.

Yu, O. Y.; Zhao, I. S.; Mei, M. L.; Lo, E. C. M. \& Chu, C. H. Dental biofilm and laboratory microbial culture models for cariology research. Dent. J. (Basel), 5(2):21, 2017.

Zhang, X.; Zhao, C.; Xiang, N. \& Li, W. Chain entanglements and hydrogen bonds in carbopol microgel reinforced hydrogel. Macromol. Chem. Phys., 217(19):2139-44, 2016.

Dirección para Correspondencia:

Rodríguez Luis Osvelia

Universidad Autónoma de Nuevo León

Facultad de Odontología 64460

Monterrey

Nuevo León

MÉXICO

Email: osvelia.rodriguezls@uanl.edu.mx 